
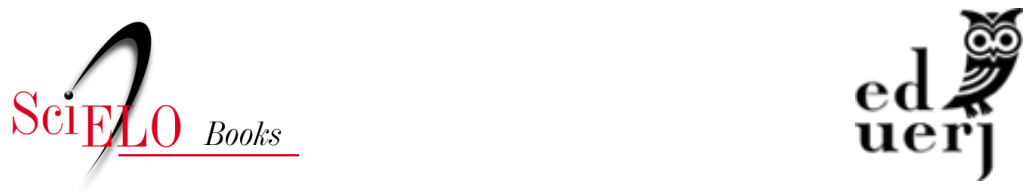

\title{
Heterarquias conhecimento. As instituições de ensino superior. Papéis e funções de Marília/SP na rede urbana
}

\author{
Pablo Muryllo de Oliveira \\ Márcio José Veríssimo Catelan
}

\section{SciELO Books / SciELO Livros / SciELO Libros}

OLIVEIRA, P. M., and CATELAN, M. J. V. Heterarquias conhecimento. As instituições de ensino superior. Papéis e funções de Marília/SP na rede urbana. In: MAIA, D. S., and MARAFON, G. J., eds. Ensino superior e desenvolvimento regional: reconfigurando as relações entre as cidades e o campo [online]. Rio de Janeiro: EDUERJ, 2020, pp. 82-117. ISBN: 97865-87949-08-6. https://doi.org/10.7476/9786587949086.0004.

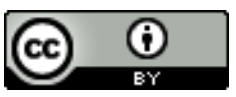

All the contents of this work, except where otherwise noted, is licensed under a Creative Commons Attribution 4.0 International license.

Todo o conteúdo deste trabalho, exceto quando houver ressalva, é publicado sob a licença Creative Commons Atribição 4.0.

Todo el contenido de esta obra, excepto donde se indique lo contrario, está bajo licencia de la licencia Creative Commons Reconocimento 4.0. 


\title{
HeteraRquias CONHECIMENTO. As INSTITUIÇÕes DE ENSINO SUPERIOR. PapéIS E FUnÇÕes DE MARÍlia/SP NA REDE URBANA
}

\author{
Pablo Muryllo de Oliveira \\ Márcio José Veríssimo Catelan
}

\section{Introdução}

As redes são a base para entendermos a estruturação do espaço, principalmente a partir das revoluções industriais e tecnológicas que ocorreram durante a história da humanidade. Partindo do entendimento de que o espaço é articulado e estruturado pelas redes, diversos autores contribuíram com seus estudos para apreendermos como o espaço é produzido, bem como suas diversas relações. Um dos autores a pensar o espaço a partir de uma estruturação em rede foi Walter Christaller (1933). O estudo desse geógrafo contribui imensamente para entendermos que existe uma hierarquização espacial e essa ideia forneceu elementos teórico-metodológicos para que Instituto Brasileiro de Geografia e Estatística (IBGE) caracterizassem e classificassem os centros urbanos brasileiros.

Nesse sentido, o IBGE, a partir das contribuições de Christaller, publicou, em 1972, o primeiro estudo sobre a rede urbana brasileira, intitulado de Região de Influência das Cidades (REGIC). Esses estudos são realizados, pelo menos, uma vez por década, tendo publicações em 1987, 1993, 2003 e, o mais recente, em 2007. Nessas 
publicações, além do aspecto teórico-metodológico que embasam a pesquisa, são apresentados diversos mapas que ilustram as diversas redes urbanas do território brasileiro e de suas articulações. Esses mapas mostram a abrangência e a amplitude de atuação de cada cidade na rede e, também, sua posição na hierarquia urbana, tendo como parâmetros para sua classificação a complexidade de seus papéis e funções que são desempenhadas perante o conjunto de cidades. Essa pesquisa elaborada pelo IBGE é extremamente importante e rica em informações para entendermos a formação espacial, em rede, do território brasileiro. Sendo assim, o estudo traz diversos aspectos comparativos de tempo pretéritos das redes urbanas e que podem ser comparados ao atual contexto das cidades brasileiras.

Entretanto, como toda teoria ou modelo explicativo de algum fenômeno ou processo, a Teoria das Localidades Centrais tem limitações. Essas limitações partem, principalmente, da sua contextualização histórica. Os estudos de Christaller são do início do século passado e, nessa época, não havia ocorrido o grande avanço técnico e tecnológico da Guerra Fria e que culminou na Globalização, que teve seu início, como já foi citado, na década de 1970. Esse período (Globalização) se distinguiu em nossa história com a rápida difusão das redes imateriais, articuladas pelos satélites e pelo surgimento da internet. Esse processo redefiniu abruptamente o modo como o espaço é produzido atualmente, tendo como principais características dessa fase a instantaneidade, o signo da velocidade e as técnicas (Santos, 2006). Desse modo, o IBGE, em sua publicação da REGIC de 2008, considerou a

introdução de novas tecnologias e alterações nas redes técnicas, o aprofundamento da globalização da economia brasileira e o avanço da fronteira de ocupação imprimiram modificações marcantes no território, o que indica a oportunidade de atualizar-se o quadro das regiões de influência das cidades (IBGE, 2008, p.9). 
O paradigma da Hierarquia Urbana nos ajuda a entender a estruturação mais rígida das redes urbanas, mas esbarra nas inovações técnicas e nas novas articulações entre as redes, cidades, empresas e pessoas que esses avanços possibilitaram. Essas novas interações redefiniram e ampliaram, em quantidade e qualidade, as escalas de atuação de processos e fenômenos sociais, espaciais e econômicos. Desse modo, aparece uma forma complementar aos conteúdos contemporâneos do padrão hierárquico a fim de compreender o complexo arranjo entre escalas, redes e cidades que é a Heterarquia Urbana - noção denominada por Catelan (2013) para se compreender interações complexas da rede urbana, que vamos tomar como ponto de partida para nossa leitura na cidade de Marília/SP.

Nesse contexto, a rede urbana é, então, lida a partir de um par hierarquia-heterarquia, buscando compreender como na cidade de Marília, seus papéis e funções, com a presença de grandes equipamentos como as Instituiçôes de Ensino Superior (IES), são exercidos por esta cidade, promovem um reforço do padrão hierárquico, mas combinado com as relações e articulações inter e multiescalares que valorizamos por meio da proposta da heterarquia urbana.

\section{As Redes Geográficas, as Interaçóes Espaciais Interescalares e a Heterarquia Urbana}

A Heterarquia Urbana se pauta intrinsicamente nas interações espaciais interescalares decorrentes das conexões, articulações e seus fluxos na rede urbana em múltiplas escalas (Catelan, 2013). Nesse sentido, esse conceito tem como premissa de que a estruturação em rede de cidades vai além daquelas definidas pelo paradigma da Hierarquia Urbana, e que os fluxos no movimento relacional do espaço atingiram uma complexidade maior que aquela revelada pelo padrão hierárquico. Esses movimentos condizem com os vetores horizontais e extrapolam o padrão verticalizado e hierarquizado proposto pela Teoria das Localidades Centrais elabo- 
rada por Christaller (1933). As relações entre as cidades não estão condicionadas unicamente por interações e um mesmo extrato da rede urbana. Uma cidade que está abaixo da metrópole na hierarquia urbana mantém interações com outras cidades de níveis hierárquicos diferentes e de outras redes na qual ela não pertence, sem necessariamente ter que "passar”, de algum modo, por degrau a degrau da rede urbana. Essas interações e fluxos só foram possíveis com o adensamento da complexidade espacial que pode ser compreendida a partir do meio técnico-cientifico-informacional (Santos, 2006). Assim sendo, as redes se tornam mais complexas e as escalas de atuação das cidades e empresas se ampliaram, tanto em quantidade como em qualidade.

A noção de Heterarquia Urbana, elaborada por Catelan (2013), explicita e denomina o que sempre chamamos de relações "não hierárquicas" que ocorrem na rede urbana. Revela, também, as interações entre o espaço, tempo, movimento (Santos, 1998) e as escalas geográficas, utilizando-as como recurso analítico para entendermos a atual configuração do conjunto de cidades articuladas em redes. Para ajudar a definição de como se dão essas articulações, o autor utiliza o conceito de interações espaciais que já foi trabalhado por muitos outros autores, mas que não a utilizavam "como uma perspectiva metodológica para a construção de uma teoria espacial de articulações entre escalas” (Catelan, 2013, p. 37). As interações espaciais, desse modo, são todos os movimentos da sociedade no espaço, e que elas podem ser "as intra e interurbanas, as intrarrede e as que se dão entre redes de cidades" (Catelan, 2013, p. 12).

Nessa perspectiva, das interações espaciais interescalares, ocorrem a ressignificação das múltiplas escalas dos processos urbanos. Essa ressignificação parte das articulações entre as escala local, regional e global que o processo de globalização possibilitou. Desse modo, os papéis e funções de cada cidade na rede urbana vão sendo alterados e complexificados trazendo novos conteúdos e formas 
mais relacionais de estruturação da rede urbana. Essa estruturação não é percebida somente pelo padrão hierárquico por que

Valorizamos aqui a diferenciação das funções e dos papéis desempenhados pelas cidades. $\mathrm{O}$ padrão hierárquico continua a existir, no entanto, torna-se insuficiente para explicar os conteúdos advindos do aumento das interações espaciais sob a égide da globalização. Os nós das redes ampliam-se não somente em quantidade, como também em complexidade técnica, territorial e econômica, ocorrendo maior sinergia entre os papéis de cada cidade na rede urbana, em cada escala geográfica e na interação entre elas (Catelan, 2012, p. 61).

A Heterarquia Urbana não substitui ou exclui o paradigma da Hierarquia Urbana, pelo contrário, ela salienta as relações hierárquicas que ocorrem na rede urbana e, ao mesmo tempo, avança na direção de pensarmos a realidade urbana a partir das duas perspectivas analíticas. Portanto, a hierarquia e a heterarquia urbana se completam e possibilitam um melhor entendimento desse complexo arranjo entre redes, escalas, movimento, espaço e tempo que reconfiguram as cidades, seja no âmbito de sua morfologia urbana, ou de seus papéis e funções desempenhadas na rede urbana, e, por consequência, no sistema urbano brasileiro. ${ }^{11}$

\section{O par hierarquia-heterarquia: uma proposta teórico-met- odológica para as análises das cidades articuladas em redes}

Além desses pontos que elencamos, vale ressaltar que em Catelan (2013) e Sposito e Catelan (2014) a proposta teórico-metodológica que pode nos ajudar a entender as cidades médias - mas

1 Sposito (2018) entende como sistema urbano brasileiro a articulação das diversas redes urbanas brasileiras, ou seja, uma rede de redes urbanas. 
não apenas esse tipo de cidade - no contexto da globalização, e que são articuladas e potencializadas pelas e por diversas redes (técnicas e urbanas), avançou para uma construção de um par dialético, o que, para nós, aparece como uma proposta capaz de oferecer elementos para compreendermos as relações na produção da cidade de Marília e seus conteúdos. Essa proposta parte, então, do pressuposto de pensarmos essas cidades a partir de um par dialético. Esse par seria composto pela Hierarquia Urbana e pela Heterarquia Urbana. A Hierarquia Urbana, como já destacamos, é baseada nas ideias do paradigma das Localidades Centrais de Walter Christaller (1933), tem um cunho quantitativo e classifica em níveis de funcionalidade as cidades de uma dada rede urbana, a partir da complexidade dos papéis e funções, que cada Localidade Central detém, sendo assim, ela cria um parâmetro vertical de cidades que "comandam" e cidades que são "comandadas". Já a Heterarquia Urbana foi elabora por Catelan (2012) e, em suma, nos ajuda a pensar as cidades a partir das relações horizontais que elas têm, tendo em vista seu complexo arranjo em redes (materiais e imateriais) que as articulam em múltiplas escalas. Sposito e Catelan (2014), pensando nas potencialidades de cada modo de estruturação em rede dessas cidades, os autores propuseram o par Hierarquia-Heterarquia Urbana como modo de pensarmos a complexidade que está posta.

São relações de interações entre o espaço, tempo e escalas geográficas, que agregam maior funcionalidade as cidades, e que modificam a inserção das lógicas advindas da escala global, como também às de cunho local e regional, de forma que não se sobreponha de forma hierárquica, num contexto onde as ações tenham um sentido vetorial único e verticalizada, mas que as influências tenham uma horizontalidade, e uma inter e múltipla escalaridade. Aonde as mudanças locais e regionais também influenciam na escala global, transformando na maneira em que as ações de escalas de níveis hierárquicos superiores produzam tal espaço (Oliveira, 2017, p. 30). 
Para entendermos o contexto da cidade e o urbano na atualidade, faz-se necessário utilizarmos ferramentas teórico-metodológicas para auxiliar nossas análises. Nesse sentido, utilizaremos uma proposta elaborada por Catelan e Sposito (2014), que visa, em suma, pensar as cidades e a urbanização contemporânea a partir das inúmeras redes que se formam e que se articulam, a partir de cada cidade e entre as cidades. A premissa dos autores parte da ideia de pensarmos essas cidades no âmbito da rede urbana em toda sua complexidade e possibilidades de articulações. É a tentativa de entender os aspectos quantitativos e qualitativos da cidade estrutura em rede e suas conexões.

O organograma 1 ilustra a estrutura teórico-metodológica que os autores da proposta organizaram, a fim de evidenciar as possibilidades analíticas da utilização do par hierarquia-heterarquia para a o estudo da rede urbana, sob a égide do processo de globalização.

Organograma 1 - Estrutura teórico-metodológica para leitura do par Hierarquia-Heterarquia Urbana

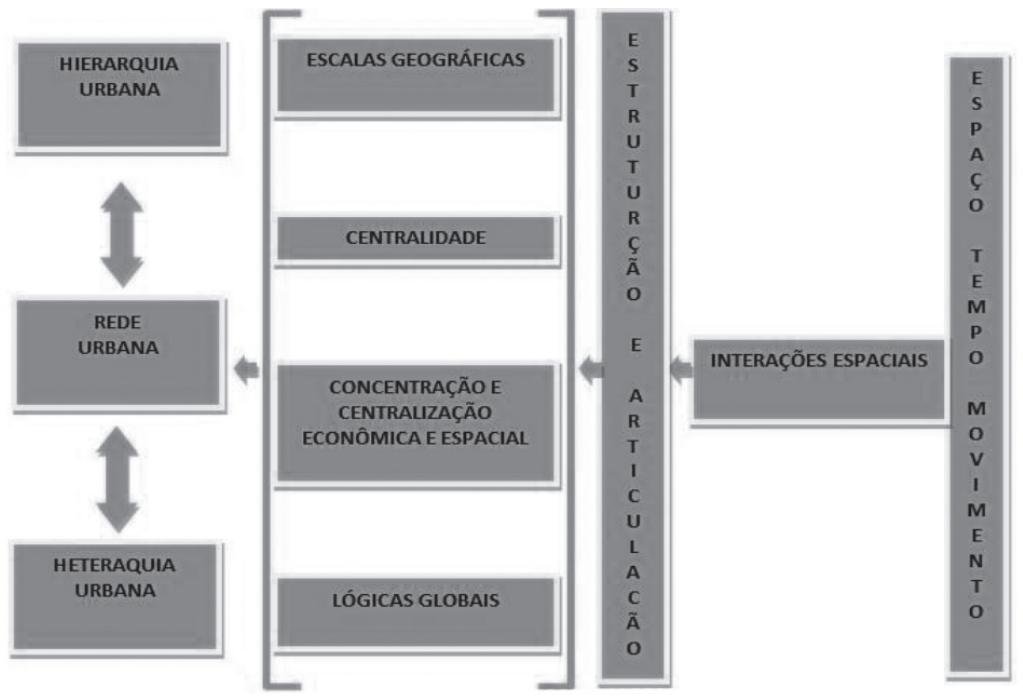

Fonte: Sposito e Catelan (2014). Extraído de Catelan (2016). (Tradução nossa) 
As ideias se complementam (Hierarquia e Heterarquia Urbana) a fim de nos ajudarem na elaboração de um arcabouço teórico-metodológico, que nos ofereçam elementos para os estudos na área de Geografia Urbana, e não apenas para os estudos das Cidades Médias.

Na era da Globalização, é necessário utilizar novas possibilidades e perspectivas teóricas para analisar a urbanização contemporânea. Os conteúdos elencados por Catelan (2016) para se compreender as relações complexas na rede urbana - Escalas Geográficas, Centralidade, Concentração e Centralização Econômica e Espacial, e Lógicas Globais - são dimensões analíticas pelas quais poderemos compreender a cidade de Marília e as relações que nela se deram quando articulamos a presença das universidades, a consolidação das indústrias do setor alimentício e os equipamentos e serviços de saúde. Portanto, a partir do par hierarquia-heterarquia, fica evidente que as estruturações das redes e das escalas se redefinem, como também, os papéis e funções urbanas desempenhadas por cada cidade. Desse modo, a capacidade de atrair, dispersar e articular os diversos fluxos que circulam nas redes se redefine, alterando, assim, a centralidade urbana de cada nó da rede.

\section{Fluxos, fixos, escalas, articulações em redes e movimentos: a constituição das Centralidades Urbanas}

As cidades médias são cidades que exercem um papel importante na configuração da rede urbana. Essas dinâmicas são condicionadas e condicionantes da produção do espaço intra e interurbano e, de certo modo, (re)configuram sua atuação em múltiplas escalas geográficas. Partindo disso, expomos a maneira que entendemos como se configuram essas cidades, tendo em vista as centralidades que elas exercem, seja em um nível local (intraurbano) ou regional (interurbano) articulada pelas redes, que se configuram e reconfigu- 
ram-se a partir dessas articulações, não deixando de lado os ditames do processo de urbanização atual e da globalização.

Claval (2000), referenciando a interpretação geográfica da centralidade, afirma que ela não é uma "propriedade geométrica estável”, pois depende dos fluxos de pessoas, ideias, mercadorias, capitais etc., e que essas interações foram afetadas pelo processo de densificação dos meios de comunicação e transporte cada vez mais rápidos.

Revisitando a obra máxima de Milton Santos (A Natureza do Espaço, 1996), o autor nos traz a possibilidade de entendermos o espaço a partir dos fixos e fluxos. Sabemos que é uma hipótese inicial e que vai se complexificando durante a obra do autor, resultando no conceito de espaço, no qual ele expressa a complexidade da realidade geográfica a partir dos sistemas de objetos e o sistema de ações.

O espaço é formado por um conjunto indissociável, solidário e também contraditório, de sistemas de objetos e sistemas de ações, não considerados isoladamente, mas como o quadro único no qual a história se dá. No começo era a natureza selvagem, formada por objetos naturais, que ao longo da história vão sendo substituídos por objetos fabricados, objetos técnicos, mecanizados e, depois, cibernéticos, fazendo com que a natureza artificial tenda a funcionar como uma máquina. Através da presença desses objetos técnicos: hidroelétricas, fábricas, fazendas modernas, portos, estradas de rodagem, estradas de ferro, cidades, o espaço é marcado por esses acréscimos, que lhe dão um conteúdo extremamente técnico (Santos, 2006, p. 39).

Santos propõe, nesse sentido, que o sistema de objetos, em suma, é a realidade materializada pela sociedade em objetos fixos no território, tendo a perspectiva das materialidades do espaço. Já os sistemas de ações seriam as relações sociais e as ações (econômicas, políticas, administrativas, capitalistas etc.), de forma simplista, 
os fluxos, de todos os tipos, materiais e imateriais. Desse modo, é importante ressaltarmos a relação dialética entre fixos e fluxos, verticalidades e horizontalidades, materialidade e imaterialidade, espaço e tempo. Todos esses pares estão contidos na definição de Espaço Geográfico de Milton Santos, sintetizada pelo par: sistema de objetos e sistema de ações. Sendo assim,

Os elementos fixos, fixados em cada lugar, permitem ações que modificam o próprio lugar, fluxos novos ou renovados que recriam as condições ambientais e as condições sociais, e redefinem cada lugar. Os fluxos são um resultado direto ou indireto das ações e atravessam ou se instalam nos fixos, modificando a sua significação e o seu valor, ao mesmo tempo em que, também, se modificam (Santos, 1982, p. 53 e Santos, 1988, pp. 75-85).

Partimos da compreensão de "que não existe cidade sem centralidade" (Whitacker, 2003, p.127). Desse modo, toda cidade (pequena, porte médio ou grande), no âmbito demográfico, ou a partir das suas relações hierárquicas e heterárquicas em redes urbanas, mantém no mínimo um centro. Além disso, partimos do pressuposto de que essa realidade pode ser alterada, ou seja, uma cidade com uma configuração monocêntrica (com apenas um centro) pode ser alterada e passar a ser uma cidade policêntrica e/ou multicêntrica ou vice-versa. Segundo Whitacker (2010), a Policentralidade é percebida na estruturação intraurbana, uma manifestação de várias áreas centrais, ou seja, o centro tradicional, subcentros ou equipamentos urbanos e instituições que tenham centralidade. Já a Multicentralidade diz respeito ao entendimento de que as diversas áreas centrais mantêm articulações escalares em diversos níveis (interurbano, interescalar e multiescalar), e não apenas na escala local (intraurbano). É nesse sentido e visando ao entendimento das multiescalaridade, que esse texto vai explorar as dinâmicas atinentes as categorias de análise do espaço: Estrutura, processo, função, forma (Santos, 1985) 
e símbolos (Corrêa, 2009) e as centralidades para analisarmos as cidades médias, e em especial a cidade de Marília.

Assim sendo, a utilização dessas categorias nos auxilia na proposta de analisar as centralidades que são geradas em Marília a partir das suas interações espaciais interescalares, sem deixar de lado sua historicidade e espacialidade. Em texto escrito por Corrêa, o autor explora as categorias de análise do espaço de Milton Santos, além de propor o acréscimo de mais uma categoria, que permeia as outras quatro: o significado.

Milton Santos define brevemente as quatro categorias, considerando como estrutura a própria sociedade com suas características econômicas, sociais, políticas e culturais. Processo é considerado como o conjunto de mecanismos e ações a partir dos quais a estrutura se movimenta, alterando se as suas características. Função, por sua vez, diz respeito às atividades da sociedade, redefinidas a cada momento, que permitem a existência e reprodução social. Forma, finalmente, é definida como as criações humanas, materiais ou não, por meio das quais as diversas atividades se realizam. Receptáculo ou recipiente, pode ser um prédio, uma rua, um bairro, uma cidade, uma área agrícola. A forma se manifesta em várias escalas, tendo uma localização e um dado arranjo espacial. Trata se, sem dúvida, de forma espacial (Corrêa, 2009, p. 1).

A incorporação dos Significados, que se torna um complemento às categorias já definidas por Santos para a análise do espaço, contribui para entender o espaço como a representação simbólica de determinada sociedade. Suas formas, usos e funções são atribuídos de modos diferentes por cada sociedade em épocas e locais diferentes. "As formas podem ser vistas em muitos casos, como simbólicas espaciais" (Corrêa, 2005).

Partindo das definições já expostas, temos o entendimento da Estrutura a partir da história do município e a implantação e conso- 
lidação da cidade, além da sociedade que ali foi formada, tendo em vista suas interações espaciais e seus agentes econômicos, políticos, sociais, culturais e religiosos. Essa estruturação é importante para analisarmos o presente, tendo como base o passado, facilitando o entendimento dos movimentos que levaram ao município de Marília conteúdos que expressam o perfil socioeconômico, produtivo, seus papéis e funções urbanas nos dias atuais. Os Processos, nesse sentido, seriam aqueles que originaram e consolidaram as IES, suas centralidades e suas sinergias, gerando interações espaciais que ajudam a construir uma posição da cidade na rede urbana. As Formas seriam aquelas que foram produzidas pelos diversos processos e que dão materialidade à cidade de Marília durante todo o percurso de sua história. Já a função advém tanto da forma como foi produzida nesse processo quanto dos conteúdos que dão movimento a elas, como os diferentes usos e apropriação do solo urbano em sua historicidade. Os símbolos seriam o conteúdo imaterial dado por essa sociedade que se originou e se consolidou, no tempo e no espaço de Marília. Estes estão materializados nas formas da cidade, nos elementos fixados no território. As formas da/na cidade são oriundas dos processos que ali foram gerados. Que foram intimamente condicionadas pela estrutura da sociedade que habitou e habita a cidade, influenciada pelos seus movimentos e seus fluxos.

Todos os aspectos aqui descritos são dialéticos, ou seja, eles condicionam intrinsicamente um ao outro, assim como são condicionados. Todas as cinco categorias se relacionam e são condicionantes e condicionadoras, entre si. Desse modo, as categorias aqui expostas são importantes para análise do sistema urbano.

Desse debate, é a relação com a construção das centralidades que resulta em nosso recorte empírico e analítico. Estas se dão pela combinação entre todas as cinco categorias de análise: Estrutura, Processo, Função, Forma e Significados, considerados dialeticamente e indissociáveis. Além delas, podemos considerar, em suma, que as centralidades se dão, a partir, dos fixos, dos fluxos, entre as 
escalas e as redes. Esses pontos que salientamos estão no âmbito das categorias de análise proposta por Santos (1985) e Corrêa (2009).

Mas não podemos nos assentar apenas nessa definição, por mais explicativa e didática que ela seja. Precisamos entender que a centralidade não está restrita a um conteúdo territorial, ou seja, a um recorte territorial específico. A centralidade gera uma forma espacial, o centro, mas não está restrita apenas a este. O centro é a materialização da centralidade, são as formas, os fixos, o sistema de objetos, articuladas por redes de transporte e de telecomunicação, por onde percorrem os fluxos de todos os tipos. A centralidade não se restringe ao centro como conhecemos, o centro tradicional, já consolidado, e que na maioria das vezes, pode ser (ou não) o centro histórico (Whitacker, 2017).

O incremento, a disseminação e a difusão desses fluxos têm contribuído para a formação de centros e não apenas de um centro na cidade. [...] Desse modo, novas e velhas expressões de centralidade ocupam, ou não, os mesmo territórios. A base territorial dessa centralidade passa, cada vez mais, a se mostrar distribuída na cidade e mesmo fora dela, no âmbito da aglomeração urbana, pois os centros tendem a possuir especializações socioeconômicas, temáticas e lúdicas (Whitacker, 2017, pp. 149-50).

Além desse conteúdo, que nos remete ao deslocamento de pessoas, mercadorias, capital, ideias etc., os fluxos, como já citado, são resultados direto ou indireto das açôes. Ou seja, seria basicamente uma "via de mão dupla", partindo da concepção de relações horizontais e verticais. Essas articulações pressupõem que os fluxos têm um caráter multiescalar e interescalar, no sentido que essas interações espaciais interescalares (Catelan, 2013) podem partir do global, impondo, articulando ou se contrapondo ao local, ou vice-versa. Essas lógicas não ficam restritas apenas a essas duas esca- 
las (global e local), mas nas diversas manifestações dos processos geográficos e suas respectivas escalas de atuação.

Sendo assim, Brandão (2008) contribui com sua visão ampla sobre as escalas e suas diversas possibilidades de interações, trazendo "a necessidade de pensar e apreender simultaneamente capitalismo(s) no plural e no singular, não existindo um modelo canônico de capitalismo, mas uma pluralidade de vias e trajetórias históricas e arranjos institucionais possíveis". Para o autor, o capitalismo age em múltiplas escalas, alterando-as e criando novas escalas de atuação e redes que a conectam. Desse modo, as transformaçóes oriundas do capitalismo se realizam e se expressam em múltiplas escalas. Nos pautamos a partir deste conteúdo para ler a articulação na presença da IES, das indústrias alimentícias e dos equipamentos de saúde articulados à produção da cidade de Marília e a definição de seus papéis e funções.

Nessa mesma perspectiva de uma produção capitalista do espaço, trazemos a definição de Corrêa, acerca do espaço urbano, um dos lócus de nosso trabalho, e que se faz necessária para o nosso entendimento sobre as perspectivas da urbanização sob a égide do capitalismo.

O espaço urbano capitalista - fragmentado, articulado, reflexo, condicionante social, cheio de símbolos e campos de lutas - é um produto social, resultado de ações acumuladas através do tempo, e engendradas por agentes que produzem e consomem o espaço. São agentes sociais concretos, e não um mercado invisível ou processos aleatórios atuando sobre um espaço abstrato. A ação destes agentes é complexa, derivando da dinâmica de acumulação de capital, das necessidades mutáveis de reprodução das relações de produção, e dos conflitos de classe que dela emergem (Corrêa, 1989, p. 11).

Essas interações entre as escalas e o seu estudo se fazem necessárias para o aprofundamento dos debates sobre a urbanização contemporânea. Os processos que ocorrem podem vir a ter essa face 
particular, singular, una, e uma face geral, plural, múltipla, em um sentido amplo de interpretações das quais decorrem as perspectivas teóricas e empíricas acerca do urbano e sua produção pautada na acumulação, concentração e centralização do capital; como também a partir da dispersão e desconcentração da produção pelo território.

Podemos perceber também que, conjuntamente com os fluxos, temos os fixos que tal localidade acumula no tempo e no espaço. Os fixos seriam as diversas formas espaciais, equipamentos urbanos e instituições (econômico-financeiras, políticas-administrativas, culturais, históricas etc.) que contribuem para o aumento dos fluxos que cada centro possui. Logo, podemos dizer que os fixos organizam os fluxos, assim como os fluxos influenciam na implantação dos fixos.

De forma geral, quanto maior o acúmulo de fixos no centro, maior a capacidade que ele terá para organizar os fluxos que a partir dele convergem/divergem e igualmente conseguirá organizar esses fluxos em uma maior área. Por outro lado, quanto mais intensos os fluxos que convergem/divergem a partir de um centro, maior o estímulo para investimentos nesse centro, o que por sua vez, reforça a sua centralidade (Silva, 2013, p. 5).

Nossa análise não parte do centro da cidade, ou seja, da forma constituída historicamente pelo processo de concentração e dispersão, mas de outros locais que geram centralidade e que foram constituídos por processos socioterritoriais e que mantém formas, conteúdos e funções diferentes perante o tempo. Isso não implica, necessariamente, que o entendimento do que é centro não importa em nossa análise. Esse entendimento é importante no sentido de que o processo de espraiamento das atividades, seja do setor público ou privado, de cunho social, simbólico, administrativo e/ou econômico, altera e reorganiza os fluxos, seja no âmbito intraurbano ou interurbano, construindo, assim, a combinação da hierarquia com a heterarquia. Do mesmo modo, a centralidade "cria formas 
espaciais distintas das anteriores, como imputa novas funções às formas pré-ocorrentes, num processo de adequação e inadequação a novas dinâmicas impostas" (Whitacker, 2017, pp. 170-1). Assim como ela não é determina por apenas uma escala de análise, e, sim, por pelo menos duas escalas: a intraurbana e a interurbana.

Novamente, vale destacar aspectos para compreendermos a centralidade. Em suma, é definida pelos fluxos, pelas articulações e pelo movimento dialético entre os diversos pontos do espaço com um conteúdo marcadamente temporal, tendo em vista sua dupla escala de atuação. Se na escala intraurbana ela dinamizaria as interações espaciais dentro de um recorte espacial específico que no caso seria a cidade, o lócus dessas interações. Nesse evento, a instalação de equipamentos ou readequação de áreas já preconcebidas podem reconfigurar os fluxos intraurbanos. Essa reconfiguração nos fluxos não traria, necessariamente, a extinção das centralidades de outros pontos dá cidade, mas sim, alterar sua funcionalidade e seu caráter simbólico (Lefevbre, 1970).

Com Lefebvre (1983), a centralidade ganha destaque como a essência do fenômeno urbano: "A centralidade constitui para nós o essencial do fenômeno urbano, porém uma centralidade considerada junto com o movimento dialético que a constitui e a destrói, que a cria ou que a extingue", à medida que seria a forma primeira de organização urbana, por meio da concentração e da dispersão que comanda.

Em nossa opinião, sua concepção não é una e abarca várias escalas e, sobretudo, a articulação destas, por meio de duas argumentações básicas: a cidade se organiza articulada em redes de produção e numa relação e articulação intraurbana e interurbana; a cidade possui estruturas morfológias e sociológicas e, nesse sentido, a centralidade também diz respeito a um lugar com conteúdo social, carregado de símbolos e representações. Essa concepção afirma que a centralidade é, em verdade, poli(multi)cêntrica e, com nuanças diferentes, é resgatada por Gottdiener (1992) e por Soja (1993). 
Para se compreender a constituição da centralidade os fluxos são os elementos determinantes. Fluxos que são incrementados pelas comunicações e telecomunicações que são traduzidas em trocas, decisões, gestão, controle e irradiação de valores. A dinâmica de concentração e dispersão cria e recria centralidades que irão ocupar e valorar diferentemente e diferencialmente territórios no tecido urbano e se traduzem em segregação socioespacial e na fragmentação urbana. Por isso, compreendemos o caráter processual da centralidade, em complementação ao centro, expressão territorial. A centralidade é expressão da dinâmica de definição/ redefinição das áreas centrais e dos fluxos no interior da cidade (Whitacker, 2010, p. 2).

Sendo assim, não teríamos apenas um centro que seria a materialização da centralidade, mas, sim, nas cidades médias, vários centros. Ou seja, a centralidade não é um atributo exclusivo da forma espacial centro, mas está distribuída em diversos pontos da cidade, ao mesmo tempo em que concentra as atividades econômicas e dinamiza os fluxos intraurbano e interurbano de determinada cidade. "Ao mesmo tempo em que há mais de um centro, encontram-se, num mesmo território, expressões de centralidade que se manifestam também de modo cambiante e efêmero" (Whitacker, 2017, p. 150). Podemos, assim, encontrar expressões de centralidade em áreas que não ocorrem relações econômicas diretas, ou seja, a compra e venda de produtos e serviços, como já consolidados nas áreas centrais.

Já na escala interurbana, ou seja, a cidade em sua relação em rede com outras cidades, essa centralidade também é modificada/ reconfigurada constantemente. A cidade reforça e/ou complexifica os papéis e funções que já detém, como também pode vir a "perder" esses papéis e funções para outras cidades, tendo em vista as dinâmicas de concorrência e complementaridade que as mesmas detêm. A centralidade é complexa e se dá pela articulação, principalmente, 
entre as centralidades que são expressas nessas duas escalas espaciais, mas não apenas nelas. Não existe apenas uma centralidade, mas, sim diversas centralidades que se articulam e dividem o espaço urbano, assim como redefine os papéis da cidade na rede urbana.

Nesse sentido, a centralidade torna-se complexa, gerando ao mesmo tempo um reforço e uma modificação na articulação dos fluxos entre a escala intra-urbana e interurbana, pois as novas centralidades compreendem uma lógica a partir da "escolha de localizações que possam ser estratégicas de sorte a atrair mercados consumidores de mais de uma cidade" (Sposito, 1998, p. 34). Por isso, reforçam a centralidade da cidade ao mesmo tempo em que multiplicam a centralidade na cidade (Oliveira Júnior, 2008, p. 216).

As cidades médias podem ser entendidas a partir do processo de globalização, sendo que esse processo facilitou a descentralização produtiva ocorrida nos anos 1970 (no Estado de São Paulo), o avanço das tecnologias de comunicação (anos 1980), que facilitaram a descentralização espacial da produção e, por conseguinte, do consumo. Todas essas "variáveis" aliadas a novas lógicas de reprodução e acumulação do capital configuram e reconfiguram as centralidades em cidades médias, assim como os seus papéis e funções perante as outras cidades (pequenas, médias e grandes; nacionais ou globais) e sua rede urbana. $\mathrm{O}$ debate sobre centralidade e cidades médias ainda contém muito conteúdo a ser exposto para a compreensão, tendo em vista que são contextos de chegada da globalização, processo este recente no território brasileiro.

Nossas dificuldades teórico-metodológicas iniciam-se quando percebemos as múltiplas dimensões escalares de atuação e expressão das centralidades, e para o entendimento e análise das dinâmicas e processos atinentes às cidades na atualidade, ampliando-se em quantidade e em qualidade. $\mathrm{O}$ entendimento das interações entre as múltiplas escalas geográficas, nesse sentido, é de extrema importância para fazermos nossas pesquisas e análises sobre as cidades médias (não apenas a essa definição de cidade). 


\section{A cidade de Marília. Uma formação socioespacial interescalar}

O sítio urbano de Marília está localizado na porção centro-oeste paulista, mais precisamente na morfoescultura pertencente à Bacia Sedimentar do Paraná e na morfoestrutura do Planalto Ocidental Paulista (Santos e Nunes, 2007). Seu relevo é do tipo Tabuliforme ${ }^{22}$ e, por esse motivo, a ocupação do território onde está localizada a área urbana tem uma intrínseca ligação com os aspectos geomorfológicos que, por sua vez, influenciaram na sua forma urbana. Por constituir este relevo, o qual é plano e com alturas que variam entre 500 a 600 metros, delimitadas pelas escarpas, ${ }^{33}$ foi propícia a instalação das infraestruturas necessárias para a linha férrea, que atendia à área padrão para a mesma, os chamados espigões, estes são também os divisores de águas. Nesse sentido, a forma do relevo favoreceu o processo de ocupação e urbanização de Marília, mas, de forma simultânea, inibiu a expansão da cidade. Esta limitação da área urbana pelas escarpas produziu dois processos socioespaciais nas áreas limítrofes: a favelização e a incorporação por agentes imobiliários de alto padrão (Santos e Nunes, 2007, p. 23).

Observa-se a partir da década de 1990 um crescimento acelerado de condomínios fechados, motivados, muitas vezes, também, pela venda da idéia de se viver próximo a natureza, além dos benefícios da segurança. Assim, no que diz respeito às ocupações das áreas limítrofes as escarpas, estas são ocupadas tanto pela população de baixa renda, através de favelas, como pela população de alta renda, através dos condomínios fechados que estabelecem preços mais elevados para os lotes mais próximos da vista "privilegiada" para os vales (Santos e Nunes, 2007, p. 23).

2 "Correspondem a chapadas, chapadões e tabuleiros que lembram à presença de mesa, ou uma extensão de mesa ou tabuleiros [...]" (Santos e Nunes, 2007, p. 20).

3 "Rampa ou declive de terrenos que aparecem nas bordas dos planaltos, serras, morros testemunhos etc." (Guerra, 1997). 
Outro elemento importante para se entender a atual localização geográfica de Marília é a presente distância com a capital do Estado: a cidade de São Paulo. As duas cidades estão separadas por rodovia, aproximadamente, em 450 quilômetros (mapa 1). Esse distanciamento foi preponderante na formação histórica e econômica do município, o que será tratado com mais detalhes adiante.

Mapa 1 - Localização de Marília perante a capital São Paulo

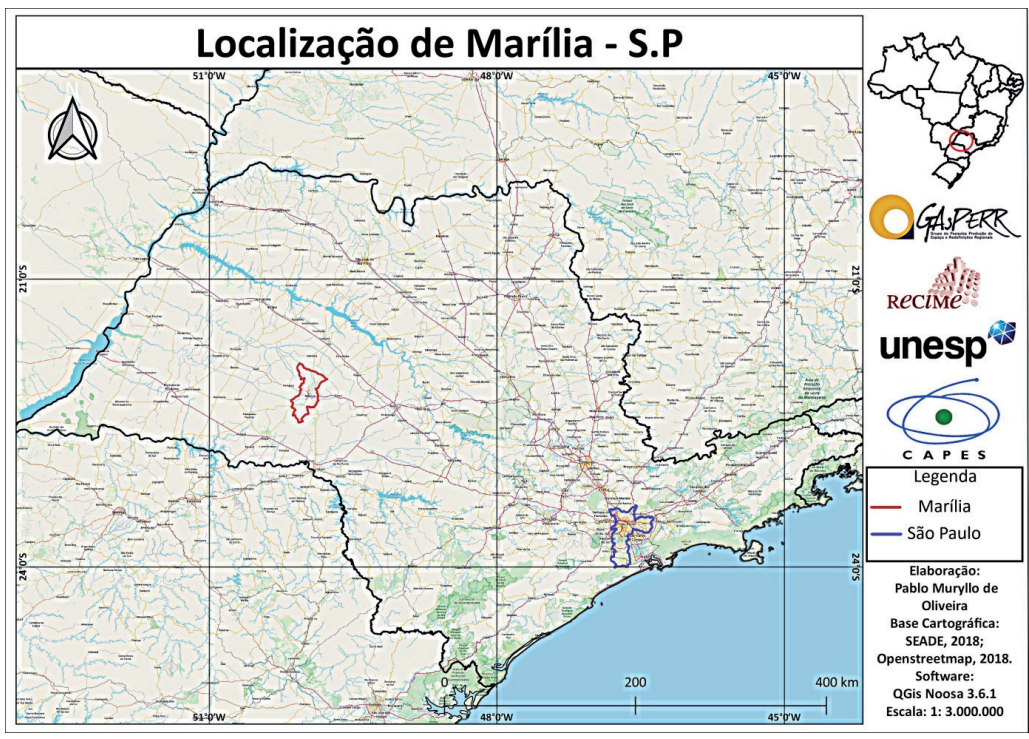

O município apresenta uma população, estimada para 2018, de 237.130 habitantes (IBGE, 2018); densidade demográfica aproximadamente de 185 habitantes por $\mathrm{km}^{2}$ (IBGE, 2010); Índice de Desenvolvimento Humano Municipal de 0,798 (IBGE, 2010), sendo considerada alta. O município configura-se, assim, na posição $47^{\circ} \mathrm{em}$ um universo de 5565 cidades, ${ }^{44}$ gerando um Produto

${ }_{4}^{4}$ Em 2013, foram instaladas cinco novos municípios no Brasil totalizando 5700 municípios atualmente. (IBGE, 2013). Disponível em: http://www.brasil.gov.br/ economia-e-emprego/2013/06/cresce-numero-de-municipios-no-brasil-em-2013 
Interno Bruto (PIB) ${ }^{55}$ total (gráfico 5) de $\mathrm{R} \$ 7.353 .418 .830,00$ (reais) em 2016 (IBGE Cidades, 2018).

A partir dos dados disponíveis no gráfico 5, é possível observar que, apesar da crise de proporções mundiais iniciada em 2008, Marília manteve um bom ritmo de crescimento do seu PIB durante os anos posteriores.

Gráfico 5 - Série Histórica do PIB de Marília de 1999 a 2016

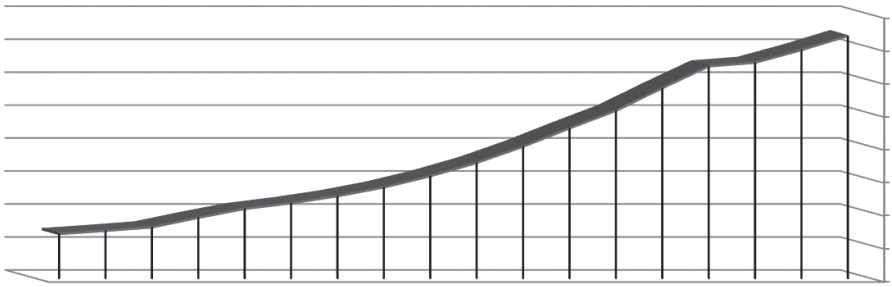

Fonte: IBGE, em parceria com os Órgãos Estaduais de Estatística, Secretarias Estaduais de Governo e Superintendência da Zona Franca de Manaus SUFRAMA

1 - Os dados do último ano disponivel estarăo sujeitos a revisăo quando da próxima divulgaçăo.

2 - Os dados da série retropolada (de 2002 a 2009) também têm como referência o ano de 2010, seguindo a nova referência das Contas Nacionais. Elaboraçåo: Pablo Muryllo de Oliveira, 2019

Fonte: IBGE, 2018.

No gráfico 6 consta a variação do PIB de Marília, por setor, durante os anos de 2010 a 2016. Nele, nota-se que os setores dos Serviços e da Indústria, durante esses anos, se mantiveram na $1^{\text {a }} \mathrm{e}$ $2^{a}$ posição (respectivamente) na composição do PIB do município. Percebe-se, também, um pequeno aumento no setor industrial, tendo um crescimento percentual em relação aos valores de 2010, de $25 \%$, mantendo pequenas oscilações com queda nos anos de $2012 \mathrm{e}$ 2013, com uma leve retomada nos anos posteriores, os dados para esse setor se mantiveram constantes. Já o setor dos serviços teve, em relação aos valores de 2010 , um aumento percentual de $83 \%$,

5 Os dados referentes ao PIB do município de Marília, não tiveram nenhum tipo de tratamento. Por exemplo: deflação, inflação ou correção monetária. 
sobressaindo assim, a proeminência das indústrias e do setor dos serviços em Marília.

Gráfico 6 - Composição do PIB de Marília de 2010 a 2016

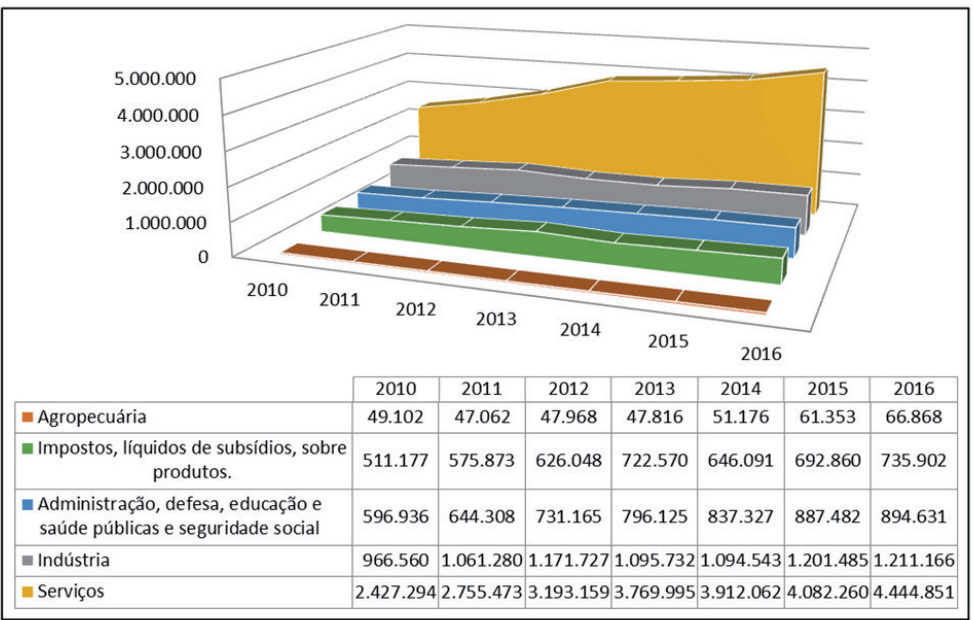

Fonte: IBGE, 2018.

Tendo observado um pouco do quadro econômico do município de Marília, analisaremos como na sua formação histórica, dando ênfase às suas fases econômicas e à instalação das indústrias, aparece o quadro de IES que, atualmente, compóem um conjunto de cursos de graduação e pós-graduação (lato e stricto sensu), alguns ligados à indústria alimentícia, outras ligadas ao setor da saúde, que também é expressão, sobretudo, do papel regional que Marília exerce.

\section{Origens das Instituições de Ensino Superior de Marília: um breve retrospecto}

Em relação às Instituições de Ensino Superior (IES), o município conta com dez instituições, as quais estão elencadas na tabela 6 , 
sendo aquelas que têm cursos presenciais no município de Marília, ou seja, com campus e instalações no município. Existem outras IES que atuam na cidade, e que mantem o módulo de Ensino a Distância (Ead). Na tabela 6, as instituições de ensino superior pública estão destacadas com um asterisco $\left({ }^{*}\right)$ e organizadas em ordem cronológica ao surgimento de cada IES.

Tabela 6 - Instituições de Ensino Superior em Marília

\begin{tabular}{lll}
\hline Instituição de Ensino Superior & \multicolumn{1}{c}{ Sigla } & \multicolumn{1}{c}{$\begin{array}{c}\text { Início das Ativ. } \\
\text { Acadêmicas }\end{array}$} \\
\hline Universidade de Marília & UNIMAR & $30 / 12 / 56$ \\
\hline Faculdade de Filosofia e Ciências* & FFC-UNESP & $13 / 01 / 59$ \\
\hline Faculdade de Medicina de Marília* & FAMEMA & $30 / 01 / 67$ \\
\hline Centro Universitário Eurípedes de Marília & UNIVEM & $08 / 08 / 67$ \\
\hline Faculdade João Paulo II & FAJOPA & $01 / 01 / 03$ \\
\hline Faculdade de Tecnologia de Marília* & FATEC & $01 / 03 / 06$ \\
\hline Faculdade de Ensino Superior do Interior Paulista & FAIP - FAEF & $01 / 01 / 07$ \\
\hline Faculdade de Marília & FAMAR - & $24 / 10 / 11$ \\
\hline Faculdade Católica Paulista & UNIESP & FACAP \\
\hline Faculdade de Ciências Jurídicas de Marília & FCJM & não iniciado \\
\hline Faculdade Anhanguera de Marília & FAM & não iniciado \\
\hline
\end{tabular}

*Universidades Públicas

Elaboração: Pablo Muryllo de Oliveira, 2019. Fonte: e-MEC, 2019

Fonte: e-MEC, 2019.

No mapa 2, estão localizadas todas as Instituiçóes de Ensino Superior de Marília. Destacamos a FAIP-FAEP, ao norte da cidade, bem próxima ao distrito industrial e, também, de várias indústrias, tais como: Cacau Foods, Carino, Dori, Manibom, ZD alimentos, entre outras. O sudoeste da cidade também se sobressai: lá, encontram-se três 
grandes universidades de Marília: a UNIVEM, UNIMAR e a UNESP. As duas primeiras são particulares e a última é pública estadual.

Mapa 2 - Localização das Instituições de Ensino Superior de Marília

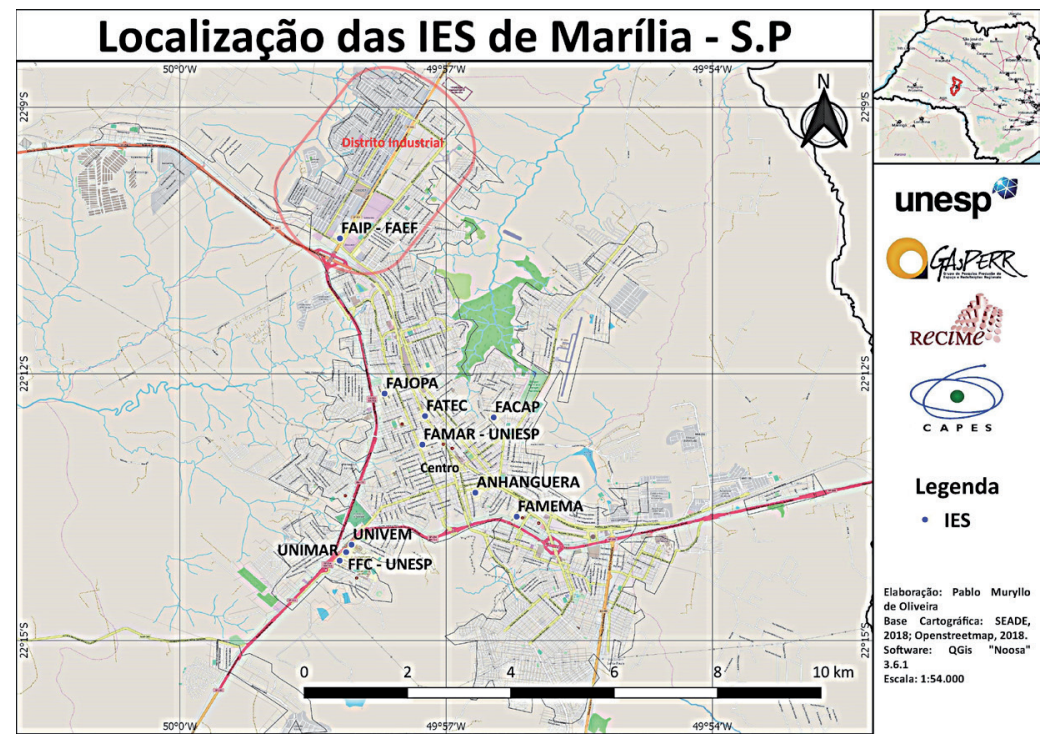

Fonte: SEADE, 2018

Além de destacarmos as suas localizações, é relevante enfatizar que as IES polarizam e dinamizam diversos fluxos em Marília, seja no âmbito intraurbano, como no âmbito da rede urbana. No intuito de entender essas dinâmicas - que partem da grande quantidade de fixos que Marília tem no setor da educação superior -, buscamos, por meio de questionários, informações que nos ajudassem a apreender sobre as dinâmicas que as IES proporcionam. Foram aplicados, ao todo, 99 questionários, que nos revelaram alguns apontamentos sobre os fluxos espaciais intraurbanos e interurbanas de Marília. É importante ressaltar que os dados que foram coletados, organizados e sistematizados para a elaboração dos mapas aqui apresentados foram obtidos com os alunos da UNESP, a única que nos recebeu e permitiu que o procedimento 
fosse aplicado. Contudo, os dados foram importantes para percebermos a potencialidade que as IES têm no sentido de reforçar a centralidade urbana de Marília e suas relações em redes, além de serem representativos, arriscamos afirmar, quando olhamos o universo do conjunto de IES em Marília.

Primeiro ponto a se evidenciar dos questionários é a diferença entre a localização das residências dos alunos que são naturais de Marília em contraposição aos alunos advindos de outras cidades. Percebe-se, no mapa 3, uma grande concentração de alunos que vieram de outras localidades para estudar em Marília. Essa concentração situa-se ao redor da área onde se localizam a UNIVEM, a UNIMAR e a UNESP. Desse modo, esse aglomerado de alunos ocorre no Jardim Araxá, mais especificamente na Rua Lauro Mascarin. O Jardim Araxá é composto basicamente de casas "geminadas" e pequenos conjuntos de prédios, que, na maioria das vezes, são preteridos pelos estudantes. Esse bairro fica ao sul da área da UNIMAR. Além dessa localidade, temos uma grande quantidade de alunos na Rua Dr. Rodrigo Argollo Ferrão, endereço onde está localizado a Moradia Estudantil da UNESP, e na Rua Tabajaras. Já os alunos que já residiam em Marília ficaram mais dispersos na mancha urbana da cidade. Outro aspecto que podemos salientar sobre essa área de concentração de residência de estudantes em Marília é que a Rua Manoel Santos Chieira, que faz divisa entre o bairro Jardim Araxá e a UNIVEM, tem diversos estabelecimentos comerciais. Na rua, encontramos posto de combustíveis, imobiliárias, mercados, restaurantes, lanchonetes, lavanderia, lojas de açaís, papelaria e buffet. A concentração de atividades comerciais nessa área pode ser entendida por três fatores e pela proximidade de dois estabelecimentos que geram a centralidade da área: 1) pela proximidade das IES (UNIVEM, UNIMAR e UNESP); 2) por estar perto das residências dos estudantes das IES; 3) por ser a rua de acesso ao Hospital da UNIMAR. Temos, assim, a intrínseca relação entre os estabelecimentos de ensino superior e de saúde na conformação de uma área com grande centralidade. Esses fluxos são mais heterogêneos, pois a atração que a área detém é diferente para cada tipo de público. O que extrapola os limites municipais 
e da cidade de Marília é a relação entre os fixos e fluxos, e nessa interação são produzidas as centralidades intraurbanas e as interações espaciais que ocorrem na escala da cidade de Marília, e que reforçam e articulam os papéis e funções que a cidade tem na rede urbana.

Mapa 3 - Localização das residências dos alunos das IES

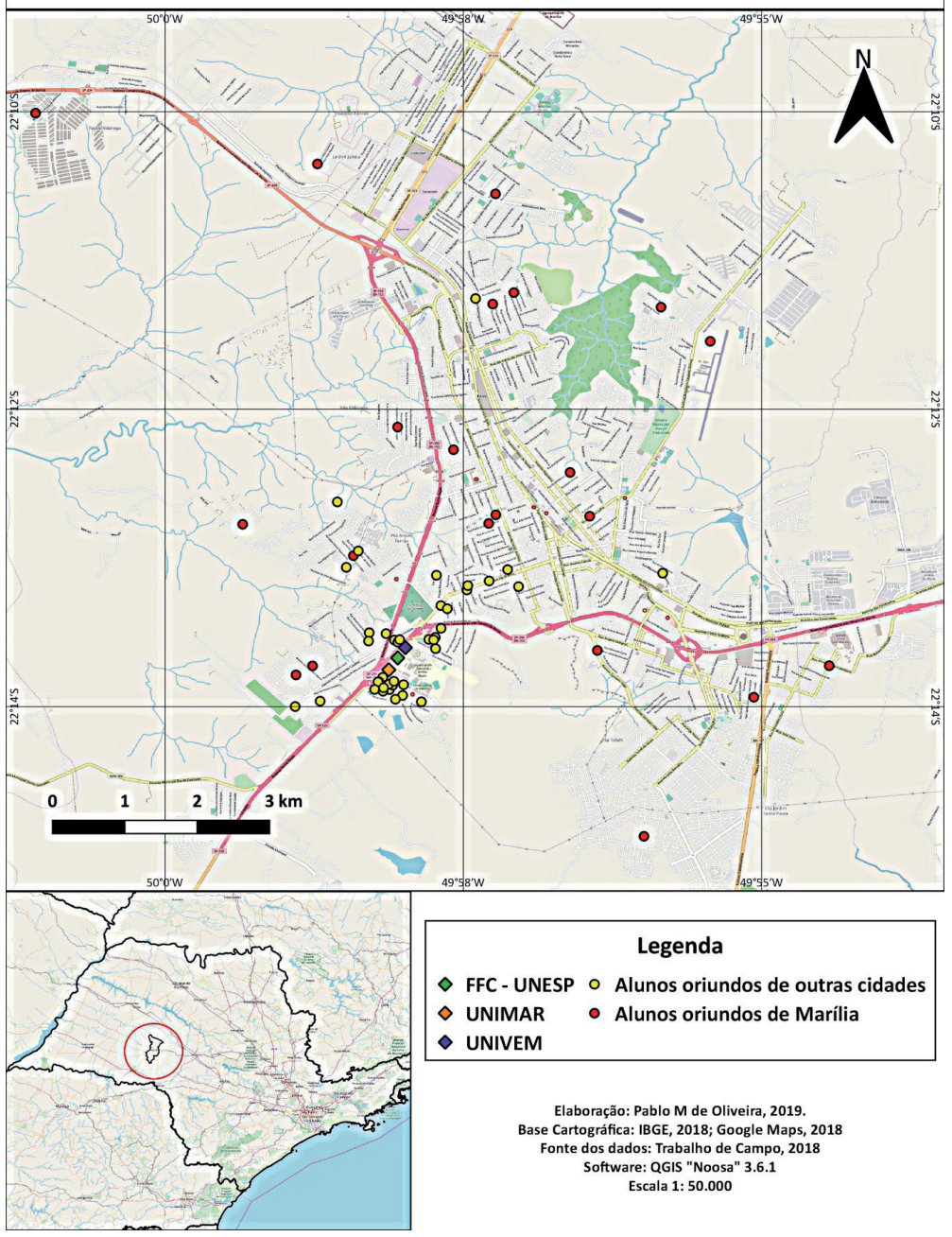

Fonte: IBGE e Google Maps, 2018 
Partindo ainda das informações obtidas pelos questionários, pudemos ilustrar no mapa 12 a origem municipal dos alunos da UNESP. Nesse mapa, não adicionamos os alunos que já residiam em Marília. Do total de questionários aplicados, são 23 alunos que já residiam na cidade e 76 alunos que vieram de 44 localidades distintas. Sendo assim, são 39 alunos que residem no Estado de São Paulo, 2 em Sergipe (precisamente em Aracaju), 3 em Minas Gerais e 1 no Rio Grande do Sul. Destacamos, primeiramente, a capital, São Paulo, com 12 estudantes advindos dessa localidade. Nesse sentido ainda, destacamos as cidades de Garça, com oito alunos; Assis, com três alunos; Gália, Oriente, Pompéia e Tupã, com um aluno cada. Essas cidades foram destacadas por serem as únicas cidades que estão na rede hierárquica da REGIC e da IX DRS (Departamento Regional de Saúde) de Marília. Portanto, todas as outras cidades que estão contidas no quadro 15 formam outra área de influência da centralidade de Marília, que é "cambiante e efêmera" (Whitacker, 2017) de Marília.

Tabela 7 - Origem municipal dos alunos da FFC-UNESP (Marília) em 2018

\begin{tabular}{llcclc}
\hline & Cidade & $\begin{array}{c}\text { Qtd de } \\
\text { Alunos }\end{array}$ & & Cidade & $\begin{array}{c}\text { Qtd de } \\
\text { Alunos }\end{array}$ \\
\hline 1 & Marília & 23 & 24 & Lavras & 1 \\
\hline 2 & São Paulo & 12 & 25 & Lençóis Paulista & 1 \\
\hline 3 & Garça & 8 & 26 & Mirandópolis & 1 \\
\hline 4 & Lins & 4 & 27 & Monte Santo de Minas & 1 \\
\hline 5 & Assis & 3 & 28 & Nova Europa & 1 \\
\hline 6 & Pres. Prudente & 3 & 29 & Oriente & 1 \\
\hline 7 & Aracaju & 2 & 30 & Osasco & 1 \\
\hline 8 & Araçatuba & 2 & 31 & Pederneiras & 1 \\
\hline
\end{tabular}




\begin{tabular}{llllll}
\hline 9 & Bauru & 2 & 32 & Pirajuí & 1 \\
\hline 10 & Botucatu & 2 & 33 & Rosana & 1 \\
\hline 11 & Jundiaí & 2 & 34 & Registro & 1 \\
\hline 12 & Pompéia & 2 & 35 & Ribeirão Pires & 1 \\
\hline 13 & S.J dos Campos & 2 & 36 & Ribeirão Preto & 1 \\
\hline 14 & Avaré & 1 & 37 & Santa Maria & 1 \\
\hline 15 & Belo Horizonte & 1 & 38 & Santos & 1 \\
\hline 16 & Caçapava & 1 & 39 & São Sebastião & 1 \\
\hline 17 & Campinas & 1 & 40 & Sorocaba & 1 \\
\hline 18 & Carapicuíba & 1 & 41 & Tietê & 1 \\
\hline 19 & Catanduva & 1 & 42 & Tupã & 1 \\
\hline 20 & Fernandópolis & 1 & 43 & Uchoa & 1 \\
\hline 21 & Gália & 1 & 44 & Vinhedo & 1 \\
\hline 22 & Itápolis & 1 & 45 & Votorantim & 1 \\
\hline 23 & Jacareí & 1 & & Total & 99 \\
\hline
\end{tabular}

Elaboração: Pablo Muryllo de Oliveira, 2019.

Fonte: Trabalho de Campo, 2018. 
Mapa 4 - Município de origem dos estudantes de Marília em 2018

\section{Origem dos alunos}

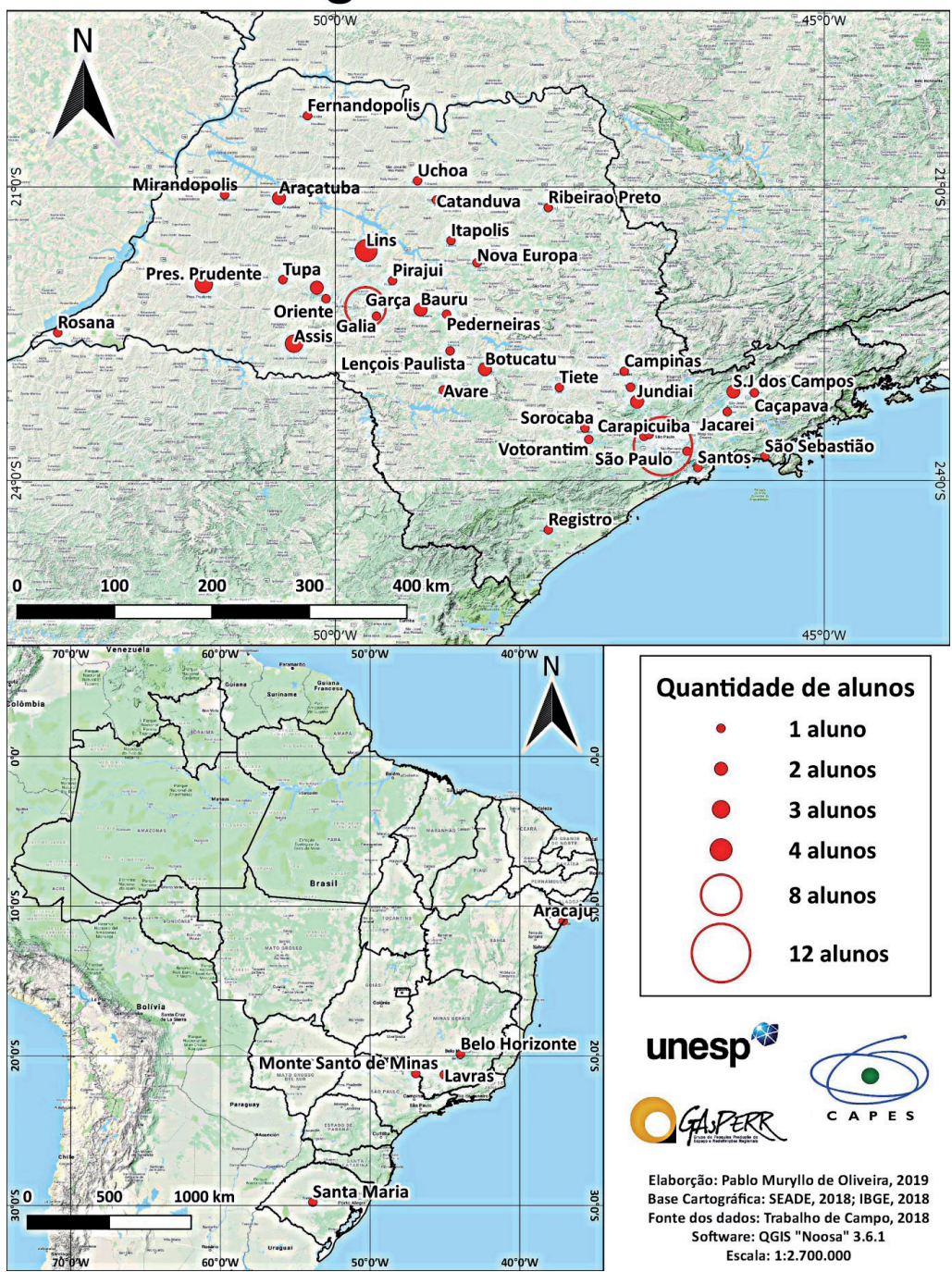


Os resultados que obtivemos, a partir dos estudantes da UNESP, são apenas umas das possibilidades de apreensão da configuração em redes de Marília. Deve ser estudado, por exemplo, o impacto econômico dessas relações em rede que têm como foco a função universitária da cidade. Ainda no sentido de explorar a rede que se forma a partir dos estudantes, destacamos que ela se altera ano a ano, conforme a origem dos alunos que buscam nas IES de Marília uma oportunidade de ingressar no ensino superior. Assim sendo, são inúmeras configurações que essa rede pode vir a ter, sendo que elas se alteram em um curto tempo, definidas pelos fluxos que ali circulam.

A centralidade, definida pelos fluxos que dão conteúdo (inclusive o conteúdo identificado por CASTELLS) ao(s) centro(s) é cambiante, à medida que não se define pela localização, mas pelo movimento e pela articulação das diferentes localizações.

Essa centralidade não se define apenas no nível intra-urbano, mas na articulação de diferentes níveis e escalas, sobretudo quando não se restringe a elaboração do modelo teórico à concepção de hierarquia urbana tradicional, mas sim se compreende a constituição de redes num padrão não necessariamente concêntrico e que possui articulações definidas por fluxos. Portanto, não apenas a definição da centralidade no tecido urbano se dá pelos fluxos e é dinâmica, mas também a centralidade pensada na escala da rede, ambas podendo, conforme características e tempos, sobreporem-se (Whitacker, 2003, p. 135).

Percebe-se, assim, que é formada uma rede onde circulam os fluxos, que são gerados pela centralidade urbana e intraurbana proveniente da UNESP. Os fluxos dessa rede não ficam restritos aos movimentos sazonais dos alunos, ela tem outras potencialidades, tais como: a circulação de capital, de mercadorias, entre outros. Assim sendo, a complexidade está posta no sentido de que são estruturadas 
redes a partir de Marília, e elas são articuladas a várias outras redes em múltiplas escalas, e como já foi observado anteriormente, essas articulações não redefinem apenas a posição da cidade na rede urbana, mas também, o seu espaço intraurbano. Sendo assim, quanto maior a centralidade urbana de Marília, maior será sua capacidade de polarização dos fluxos que circulam nas redes, e, com isso, o espaço intraurbano da cidade se modifica e vice-versa. Portanto, o mapa ilustra o caráter heterárquico das redes formadas pela centralidade das IES, pois demonstram outras articulações que Marília tem e que não são "contabilizadas", por exemplo, pelos estudos da REGIC.

\section{Considerações Finais}

Compreender a consolidação das IES na cidade de Marília/ SP trouxe ao debate mais elementos que reforçam a hipótese defendida por Catelan (2013) de que as cidades médias, muito embora posicionadas em níveis intermediários da rede urbana, têm seus papéis e funções produzidos por articulações multi e interescalares. O movimento de fora para dentro e de dentro para fora fica evidente quando analisamos as dinâmicas estabelecidas pelas IES numa cidade como Marília/SP, mas também em outras que vêm sendo pesquisadas no âmbito da Rede de Pesquisadores sobre Cidades Médias - a RECIME - e por outras muitas pesquisas dedicadas a revelar e compreender estas cidades.

Neste texto, dedicamo-nos a revelar o que de especificidades encontramos ao compreender o papel das IES em Marília/ SP. É marcadamente evidente a articulação com o setor produtivo representado, principalmente pelas indústrias de alimentos. Outra relação destacada é a articulação das IES com o setor da saúde. A presença de hospitais e uma série de empresas que atendem nesse setor também tem influenciado. Cursos de graduação e pós-graduação, lato e stricto sensu, são criados consoantes à presença dessas 
atividades que demarcam também os papéis e as funções da cidade de Marília/SP na rede urbana em diferentes escalas.

$\mathrm{Na}$ escala local, a geração de centralidades na cidade decorre, também, por conta da presença das IES. Chama a atenção o aspecto comum a muitas cidades que possuem IES, centralidade fortes geradas por elas. No caso de Marília/SP, onde estão UNIVEM, UNIMAR e UNESP, direciona-se no entorno um tipo de habitação que são os prédios de apartamentos para aluguéis.

$\mathrm{Na}$ escala regional, sem dúvida, é destacável o reforço do papel da cidade de Marília/SP tanto pelo aumento de fluxos dos alunos que vivem em cidades da área regional de influência, como também gera atividades estendidas na indústria, comércio e serviços, como os de saúde, por exemplo. Muitas cidades, como Pompeia/ SP e Garça/SP, recebem forte influência no que se refere ao setor produtivo e da saúde. Ao mesmo tempo, os papéis e as funções de Marília/SP se intensificam em decorrência da presença destes alunos, sendo que muitos passam a morar nesta cidade, o que leva também a articulações com o setor imobiliário.

Nas escalas nacional e global, as IES em Marília/SP cumprem um papel de destaque, tendo em vista que a produção do conhecimento traz não somente uma série de atividades como congressos, exposições e intercâmbios de pesquisadores, como também a própria articulação do conhecimento com a produção alimentícia e os atendimentos da saúde dinamizam os serviços de educação e pesquisa.

Podemos afirmar que a questão escalar é reconfigurada ao reconhecermos o movimento na construção dos papéis e das funções das cidades médias. Há mudanças nas articulações desde a escala local até a presença de lógicas da escala global em cidades médias como Marília/SP. Essas articulações nos permitem reconhecer que, muito embora não se altere a posição dela na rede urbana, afinal, Marília/SP continua a ser uma cidade média, as interações espaciais se dão de forma a superar a estrutura rígida da hierarquia espacial, por muito tempo pensada como único paradigma capaz 
de explicar a relação entre as cidades que cumprem papéis distintos na rede. $\mathrm{O}$ que se alterou, portanto, foi o modo de articulação. As escalas estão mais articuladas e, ao mesmo tempo que se consolidou os níveis da rede urbana, também se tornou mais fluído e articulado a relação entre lógicas na perspectiva interescalar.

Sendo assim, grandes infraestruturas e/ou equipamentos como as IES têm forte impacto na elaboração dos papéis e das funções de cidades como Marília/SP. Isso chama a atenção para agenda de pesquisa que buscamos cumprir ao olharmos para as especificidades do urbano no Brasil que só pode ser revelado ao considerarmos sua diversidade no âmbito do processo de diferenciação socioespacial. A heterarquia é, então, encontrada naquilo que gera a diferenciação na produção do espaço, lógicas que vão sendo incorporadas na produção da cidade que não podem ser explicadas apenas pelas escalas local e regional, comumente acionadas quando tratamos de níveis intermediários. Marília/SP é uma cidade média porque seus papéis e suas funções resultam das articulações interescalares e não somente porque está a meio caminho da estruturação hierárquica.

\section{Referências}

BRANDÃO, C. "Desenvolvimento, Territórios e Escalas Espaciais: levar na devida conta as contribuições da economia política e da geografia crítica para construir a abordagem interdisciplinar". In RIBEIRO, M. T. F. e MILANI, C. R. S. (orgs.). Compreendendo a complexidade sócioespacial contemporânea: o território como categoria de diálogo interdisciplinar. Salvador: Editora da UFBA, 2008.

CASTRO, I. E. "O sistema internacional contemporâneo: globalização e organizações supranacionais." In Geografia e politica: território, escalas de ação e instituições. Rio de Janeiro: Bertrand Brasil, 2005.

CATELAN, M. J. "A heterarquia urbana como proposta metodológica: dissonâncias no ritmo e no arranjo espacial da rede urbana e do mapa da indústria do estado de São Paulo". In SPOSITO, E. S. (org.). O novo mapa da indústria no início do século XXI: diferentes paradigmas para a leitura das dinâmicas 
territoriais do estado de São Paulo. 1ed. São Paulo: Cultura Acadêmica, 2015, v. 1, pp. 303-26.

. "Heterarquia Urbana e interações espaciais interescalares: proposta analítica para estudos na rede urbana”. In XIII Simpósio Nacional de Geografia Urbana, 2013, Rio de Janeiro. Ciência e Ação Politica: por uma abordagem critica, v. 13, 2013

. "Heterarquia Urbana: Interações espaciais interescalares e cidades médias”. 1. ed. São Paulo: Editora UNESP, 2013. v. 1.291 p.

CORRÊA, R. L. "Cidades médias e rede urbana". In: SPOSITO, M. E. B. e RIBEIRO, W. Perspectivas da Urbanização. São Paulo: Consequência, 2017, p. 29-38.

. Estudos sobre a rede urbana. Rio de Janeiro: Bertrand Brasil, 2006.

. "Redes geográficas: reflexões sobre um tema persistente". In Revista Cidades, volume 9, número 16,2012, pp. 200-20.

. A rede urbana. Rio de Janeiro: Ática: 1989.

. "Construindo o conceito da cidade média". In SPOSITO, M. E. (org.). Cidades Médias - Espaços em Transição. São Paulo: Expressão Popular, 2007, v. 1, pp. 15-25.

. "Globalização e Reestruturação da Rede Urbana - uma nota sobre as pequenas cidades”. Revista Territorio, ano IV, n. 6, jan.-jun.1999.

. O Espaço Urbano. São Paulo: Ática, 1989.

. Processo, forma e significado. Uma breve consideração. Disponível em: http://www.ihgrgs.org.br/Contribuicoes/Processo_Forma_Significado.htm

. Trajetórias Geográficas. 6. ed. Rio de Janeiro: Bertrand Brasil, 2011.

. "Uma nota sobre o urbano e a escala". Revista Território. Rio de Janeiro, ano VII. n. 11, 12 e 13, p. 133-36, set.-out. 2003.

MELAZZO, E. S. "Marília: especialização industrial e diversificação do consumo. Trajetórias de uma cidade média”. In SPOSITO, M. E. B. et al (orgs.) Agentes econômicos e reestruturação urbana e regional: Chillán e Marília. 1. ed. São Paulo: Outras expressões, 2012.288p. 
OLIVEIRA JÚNIOR, G. A. DE. "Redefinição da Centralidade Urbana em Cidades Médias”. Sociedade \& Natureza, Uberlândia, n. 20, v. 1, pp. 20520, jun. 2008.

OLIVEIRA, B. S. DE. “Rede Urbana Brasileira: algumas reflexões teóricas”. Revista Formação, n. 15, v. 2, pp. 100-09.

OLIVEIRA, P, M. Globalização, consumo e cidades médias: o complexo arranjo em redes hierárquicas e heterárquicas. (Monografia). Presidente Prudente: [s.n], 2017.

e CATELAN, M. J. “Arranjos Espaciais em redes Hierárquicas e Heterárquicas: a Globalização e o Comércio Exterior em Cidades Médias. Presidente Prudente, Marília e São Carlos/SP”. In: SIMPURB, 2017, Salvador - BA. XV Simpósio de Geografia Urbana, 2017.

e SANTOS, F. R. "As redes geográficas na era da globalização: algumas reflexões sobre a rede urbana em sua historicidade e na prática teórico - metodológica”. Formação (Presidente Prudente), v. 26, pp. 3-22, 2019.

SANTOS, C. A. M. DOS e NUNES, J. O. R. "Mapeamento geomorfológico do perímetro urbano do município de Marília/SP”. Geografia em Atos, v. 1, pp. 12-28, 2007.

SANTOS, C. D. DOS. "A formação e produção do espaço urbano: discussões preliminares acerca da importância das cidades médias para o crescimento da rede urbana brasileira”. GङDR, v. 5, n. 1, pp. 177-90, jan.-abr. 2009, Taubaté, SP, Brasil.

SANTOS, F. R. "Questão locacional e teorias de localização: Contextualização e análise de sua validade no período contemporâneo". Caderno Prudentino de Geografia, v. 2, pp. 120-42, 2018.

SANTOS, J. Centro, Sub-centros e novas Centralidades na Metrópole Soteropolitana. In: Anais do X Encontro da ANPEGE. Rio de Janeiro, 2007.

SANTOS, M. "Estrutura, processo, função e forma como categorias do método geográfico”. In Espaço e Método. São Paulo: Nobel, 1985.

- A Natureza do Espaço: Técnica e Tempo, Razão e Emoção. São Paulo: Editora da Universidade de São Paulo, 2006. 
. A Urbanização Brasileira. São Paulo: Editora da Universidade de São Paulo, 2013.

. "O retorno do território". In SANTOS, M. et al. In Território, globalização e Fragmentação. São Paulo: Hucitec; ANPUR, 1998, pp. 15-20.

. Por uma outra globalização: do pensamento único à consciência universal. 23 ed. Rio de Janeiro: Record, 2013.

e SILVEIRA, M. L. "A categoria de análise não é o território em si, mas o território utilizado". In: . O Brasil. O Território e Sociedade no inicio do século XXI. 9 ed. Rio de Janeiro: Record , 2006. pp. 247-86

SILVA, O. T. DA. "O Conceito de Centro e Centralidade como um instrumento de compreensão da realidade urbana”. XIII SIMPURB. UERJ. Rio de Janeiro, 2013.

SOJA, E. Geografias Pós-Modernas. A reafirmação do espaço na teoria social critica. Rio de Janeiro: Zahar, 1993.

SPOSITO, M. E. B. "Reestruturação econômica, urbana e da cidade: os papeis intermediários de cidades médias em múltiplas escalas". In: LAN, D et al (orgs.). Reestructuración productiva e industria, en ciudades intermedias de Argentina y Brasil. Tandil: Universidad Nacional del Centro de la Província de Buenos Aires, 2018, v. 1, pp. 189-207.

e CATELAN, M. J. "Hierarchy and Heterarchy in Brazil's urban network”. Brazilian Geographical Journal: Geosciences and Humanities research medium, Ituiutaba, v. 5, n.2, pp. 556-54, jul.-dez. 2014.

. Rede urbana. In: SPOSITO, E. S. (Org.). Glossário de Geografia Humana e Econômica. São Paulo: expressão Popular, 2017, pp. 347-67.

O chão em pedaços: urbanização, economia e cidades no Estado de São Paulo. (Tese). Presidente Prudente: Unesp, 2004.

e SPOSITO, E. S. "Articulações entre múltiplas escalas geográficas: Lógicas e estratégias das empresas”. Geousp - Espaço e Tempo, v. 21, n. 2, pp. 462-79, 2017.

WHITACKER, A. M. "Centro da cidade, centralidade intraurbana e cidades médias". In MAIA, D. S. et al (orgs.). Centro e Centralidade em Cidades Médias. 1 ed. São Paulo: Cultura Acadêmica, 2017, v. 1, pp. 149-78. 
e MIYAZAKI, V. "O estudo das formas da cidade no âmbito da Geografia Urbana. Apontamentos metodológicos”. Revista de Geografia e Ordenamento do Território, n. 2, dez. 2012, pp. 307-27

. "Centralidade Intraurbana e Morfologia em Cidades Médias: transformações e permanências". In: Anales del XI Seminario Internacional RII y IV Taller de Editores RIER. Mendoza: Universidad Nacional del Cuyo, 2010. v. 1. pp. 1-20. 